\title{
Correction to: DESERV IT: A Method for Devolving Service Tasks in IT Services
}

\author{
Florian Baer $\cdot$ Kurt Sandkuhl $\cdot$ Michael Leyer $\cdot$ Birger Lantow
}

(C) The Author(s) 2021

\section{Correction to: Bus Inf Syst Eng https://doi.org/10.1007/s12599-020-00655-y}

The article "DESERV IT: A Method for Devolving Service Tasks in IT Services", written by Florian Baer • Kurt Sandkuhl • Michael Leyer $\bullet$ Birger Lantow, was originally published electronically on the publisher's internet portal on 9 June 2020 without open access. With the author(s)' decision to opt for Open Choice the copyright of the article changed on 21 June 2021 to (c) The Author(s) 2021 and the article is forthwith distributed under the terms of the Creative Commons Attribution 4.0 International License, which permits use, sharing, adaptation, distribution and reproduction in any medium or format, as long as you give appropriate credit to the original author(s) and the source, provide a link to the Creative Commons licence, and indicate if changes were made. The images or other third party material in this article are included in the article's Creative Commons licence, unless indicated otherwise in a credit line to the material. If material is not included in the article's Creative Commons licence and your intended use is not permitted by statutory regulation or exceeds the permitted use, you will need to obtain permission directly from the copyright holder. To view a copy of this licence, visit http://creativecommons.org/licenses/by/4.0. Open access funding enabled and organized by Projekt DEAL.

Open Access This article is licensed under a Creative Commons Attribution 4.0 International License, which permits use, sharing, adaptation, distribution and reproduction in any medium or format, as long as you give appropriate credit to the original author(s) and the source, provide a link to the Creative Commons licence, and indicate if changes were made. The images or other third party material in this article are included in the article's Creative Commons licence, unless indicated otherwise in a credit line to the material. If material is not included in the article's Creative Commons licence and your intended use is not permitted by statutory regulation or exceeds the permitted use, you will need to obtain permission directly from the copyright holder. To view a copy of this licence, visit http://creativecommons. org/licenses/by/4.0/.

The original article can be found online at https://doi.org/10.1007/ s12599-020-00655-y.

F. Baer $(\bowtie) \cdot$ K. Sandkuhl $\cdot$ B. Lantow

Chair Business Information Systems, University of Rostock,

Albert-Einstein-Straße 22, 18051 Rostock, Germany

e-mail: Baer.Florian@gmail.com

K. Sandkuhl

e-mail: Kurt.Sandkuhl@uni-rostock.de

B. Lantow

e-mail: Birger.Lantow@uni-rostock.de

M. Leyer

Chair Service Operations, University of Rostock, Ulmenstraße

69, 18051 Rostock, Germany

e-mail: Michael.Leyer@uni-rostock.de 